\title{
Biochemical Properties and Anti-Biofilm Activity of Chitosan-Immobilized Papain
}

\author{
Diana R. Baidamshina ${ }^{1, \dagger}{ }^{\text {, Victoria A. Koroleva }}{ }^{2,+}{ }^{,}$Svetlana S. Olshannikova ${ }^{2}$, Elena Yu. Trizna ${ }^{1}$, \\ Mikhail I. Bogachev ${ }^{3}\left(\mathbb{D}\right.$, Valeriy G. Artyukhov ${ }^{2}$, Marina G. Holyavka ${ }^{2}$ and Airat R. Kayumov $1,4, * \mathbb{B}$ \\ 1 Laboratory of Molecular Genetics of Microorganisms, Kazan (Volga Region) Federal University, \\ Kazan 420008, Russia; prosto-di@mail.ru (D.R.B.); trizna91@mail.ru (E.Y.T.) \\ 2 Department of Biophysics and Biotechnology, Voronezh State University, Voronezh 394018, Russia; \\ koroleva_victoria@bk.ru (V.A.K.); Olshannikovas@gmail.com (S.S.O.); artyukhov@bio.vsu.ru (V.G.A.); \\ holyavka@rambler.ru (M.G.H.) \\ 3 Biomedical Engineering Research Centre, St. Petersburg Electrotechnical University, \\ St. Petersburg 197376, Russia; rogex@yandex.com \\ 4 Interdepartment Research Laboratory, Kazan State Academy of Veterinary Medicine Named after N.E. \\ Bauman, Kazan 420029, Russia \\ * Correspondence: kairatr@yandex.ru; Tel.: +7-(904)-665-19-08 \\ + These authors are equally contributed to this work.
}

\section{check for} updates

Citation: Baidamshina, D.R.; Koroleva, V.A.; Olshannikova, S.S.; Trizna, E.Y..; Bogachev, M.I.; Artyukhov, V.G.; Holyavka, M.G.; Kayumov, A.R. Biochemical Properties and Anti-Biofilm Activity of Chitosan-Immobilized Papain. Mar Drugs 2021, 19, 197. https://doi.org/ $10.3390 /$ md19040197

Academic Editor: Vladimir Eugenievich Yudin

Received: 11 March 2021

Accepted: 29 March 2021

Published: 31 March 2021

Publisher's Note: MDPI stays neutral with regard to jurisdictional claims in published maps and institutional affiliations.

Copyright: (c) 2021 by the authors. Licensee MDPI, Basel, Switzerland. This article is an open access article distributed under the terms and conditions of the Creative Commons Attribution (CC BY) license (https:// creativecommons.org/licenses/by/ $4.0 /)$.

\begin{abstract}
Chitosan, the product of chitin deacetylation, is an excellent candidate for enzyme immobilization purposes. Here we demonstrate that papain, an endolytic cysteine protease (EC: 3.4.22.2) from Carica papaya latex immobilized on the matrixes of medium molecular (200 kDa) and high molecular (350 kDa) weight chitosans exhibits anti-biofilm activity and increases the antimicrobials efficiency against biofilm-embedded bacteria. Immobilization in glycine buffer ( $\mathrm{pH}$ 9.0) allowed adsorption up to $30 \%$ of the total protein $\left(\mathrm{mg} \mathrm{g}\right.$ chitosan ${ }^{-1}$ ) and specific activity (U mg protein $\left.{ }^{-1}\right)$, leading to the preservation of more than $90 \%$ of the initial total activity $\left(\mathrm{U} \mathrm{mL}^{-1}\right)$. While optimal $\mathrm{pH}$ and temperature of the immobilized papain did not change, the immobilized enzyme exhibited elevated thermal stability and 6-7-fold longer half-life time in comparison with the soluble papain. While one-half of the total enzyme dissociates from both carriers in $24 \mathrm{~h}$, this property could be used for wound-dressing materials design with dosed release of the enzyme to overcome the relatively high cytotoxicity of soluble papain. Our results indicate that both soluble and immobilized papain efficiently destroy biofilms formed by Staphylococcus aureus and Staphylococcus epidermidis. As a consequence, papain, both soluble and immobilized on medium molecular weight chitosan, is capable of potentiating the efficacy of antimicrobials against biofilm-embedded Staphylococci. Thus, papain immobilized on medium molecular weight chitosan appears a presumably beneficial agent for outer wound treatment for biofilms destruction, increasing antimicrobial treatment effectiveness.
\end{abstract}

Keywords: adsorption immobilization; papain; chitosan; bacterial biofilms

\section{Introduction}

Proteolytic enzymes are widely used for various medical purposes such as debridement, as well as removal of necrotic and infected tissues in wounds or burns. Plant proteases exhibit some common advantages compared with mammalian ones because of lower risks of disease transmission [1,2]. Among them, papain (EC 3.4.22.2), an endolytic cysteine protease enzyme from the papaya (Carica papaya L.) latex, is nowadays offered as an anti-inflammatory, anti-coagulant, and hemolytic agent, also facilitating debridement and speeding up tissue recovery [3-6]. In addition, papain was reported as an anti-biofilm, anti-plaque, and anti-gingivitis agent [7-12].

Topical application of enzymes for wounds treatment is often limited by their low stability during storage due to autolysis. These limitations can be generally overcome by the enzymes' immobilization on various insoluble carriers [13-15]. Additional advantages 
of enzyme immobilization include the enhancement of their biocatalytic properties, thereby increasing their stability and reusability [16-18]. The immobilized biocatalytic complexes provide an attractive basis for the development of novel therapeutic tools for the treatment of both old and newly emerging pathologies. Compared with other enzymes, immobilization of proteases is generally limited by high molecular weight of proteins, the substrates for proteases that in turn limits the number of active enzyme molecules to those with the active center being oriented to the medium. On the other hand, immobilized proteases become protected from the auto-proteolysis, this way increasing their stability during both storage and application $[13,19,20]$.

Multiple attempts have been made to stabilize the papain, including covalent immobilization, interaction with metal ions, copolymerization with glutaraldehyde, immobilization in agarose, covalent binding with polyethersulfone, modification with succinic anhydride, simple adsorption in Celite ${ }^{\circledR}$, ion absorption, adsorption on nylon-based immobilized copper ion affinity membrane [21], adsorption on electrospun nylon nanofiber as affinity membrane [22], inclusion in starch-based gel, and incorporation in nitrile fiber enriched with amino groups, as well as immobilization on the surface of cotton fabric [23], sepharose, nanoparticles, incorporation in niosomes, nanospheres, liposomes, and many others [23-33]. In some of the latest assays, both antibacterial and anti-biofilm activities of immobilized papain have been reported [6,34]. While the above approaches generally enhanced the protein stability and its optimal temperature, reduction of the specific activity and the enzymatic reaction speed of the immobilized enzyme compared with soluble papain appeared to be their common limitations.

Chitosan, the product of chitin diacetylation, is a universal sorbent that binds with a wide range of substances of both organic and inorganic origin, thus being an excellent candidate for enzyme immobilization purposes [35-38]. Low-cost, large-scale availability, antimicrobial activity, biodegradability, non-toxicity, and bio-adhesive properties make chitosan a promising carrier for many enzymes to obtain highly active and thermostable immobilized catalysts [12,39-43]. Moreover, its biocompatibility and non-toxicity make it a potential candidate for both conventional and novel drug delivery systems. Particularly, chitosan-based matrixes are of interest in tissue engineering for controlled drug release, as well as for tissue remodeling due to its fibrous and porous properties. Besides, chitosan is absolutely safe for humans and can be completely degraded after use, thereby obtaining environmentally friendly products [44-46].

Here we show that papain immobilized on a matrix of medium molecular $(200 \mathrm{kDa})$ and high molecular $(350 \mathrm{kDa})$ weight chitosans provides topical destruction of bacterial biofilms and increases the efficiency of biofilm-embedded bacteria treatment.

\section{Results}

\subsection{Immobilization of Papain on Chitosan Matrixes}

Immobilization of papain on the matrix of either medium molecular or high molecular weight chitosans was carried out by using the adsorption-from-solution approach. The largest amount of papain (mg per $\mathrm{g}$ of carrier) adsorbed on medium molecular weight chitosan was observed when using Tris-glycine buffer ( $\mathrm{pH}$ 8.5-9.0), borate buffer supplemented with $\mathrm{KCl}$ in ( $\mathrm{pH} 8.0-10.0)$, and glycine buffer ( $\mathrm{pH}$ 8.6-10.5) (Table 1). The highest total and specific activities of immobilized enzyme were obtained after the protein adsorption from acetate buffer ( $\mathrm{pH}$ 5.0-5.8), glycine buffer ( $\mathrm{pH}$ 8.6-10.5), and Tris-glycine buffer ( $\mathrm{pH}$ 8.5-9.0).

In the case of high molecular weight chitosan, maximal protein adsorption was obtained in the borate buffer ( $\mathrm{pH}$ 8.0-10.0) supplemented with $\mathrm{KCl}$, Tris-glycine buffer ( $\mathrm{pH}$ 8.5-9.0), and glycine buffer ( $\mathrm{pH} 8.6-10.5)$ (Table 2). Highest total and specific activity of papain could be adsorbed in the acetate buffer ( $\mathrm{pH} 5.0-5.8)$, glycine buffer $(\mathrm{pH} 8.6-10.5)$, Tris-glycine buffer ( $\mathrm{pH} 8.5-9.0)$, and borate buffer supplemented with $\mathrm{KCl}(\mathrm{pH} 8.0-10.0)$. 
Table 1. The effect of buffers on papain adsorption on medium molecular weight chitosan from solution. In brackets, bound total protein, total and specific activities are shown as the percentage of their initial values, respectively.

\begin{tabular}{|c|c|c|c|c|c|c|c|c|}
\hline \multirow{5}{*}{$\begin{array}{c}\text { Buffer System } \\
0.2 \text { M Sodium acetate }\end{array}$} & \multirow{2}{*}{$\begin{array}{l}\mathbf{p H} \\
4.0\end{array}$} & \multicolumn{2}{|c|}{$\begin{array}{c}\text { Total Protein, } \\
\text { mg g Chitosan }^{-1}\end{array}$} & \multirow{2}{*}{$\begin{array}{c}\text { Protein, } \mathbf{~ m g ~ m L}^{-\mathbf{1}} \\
0.13 \pm 0.02\end{array}$} & \multicolumn{2}{|c|}{ Activity, $\mathrm{U} \mathrm{mL}^{-1}$} & \multicolumn{2}{|c|}{$\begin{array}{l}\text { Specific Activity, } \\
\text { U mg Protein }{ }^{-1}\end{array}$} \\
\hline & & $2.6 \pm 0.50$ & $(13.2 \%)$ & & $42 \pm 4.1$ & $(44.6 \%)$ & $320 \pm 30.8$ & $(33.8 \%)$ \\
\hline & 4.5 & $3.3 \pm 0.38$ & $(16.4 \%)$ & $0.16 \pm 0.02$ & $79 \pm 5.4$ & $(83.7 \%)$ & $484 \pm 33.0$ & $(51.0 \%)$ \\
\hline & 5.0 & $3.9 \pm 0.37$ & $(19.4 \%)$ & $0.19 \pm 0.02$ & $82 \pm 6.0$ & $(87.0 \%)$ & $425 \pm 30.8$ & $(44.9 \%)$ \\
\hline & 5.8 & $5.4 \pm 0.84$ & $(26.8 \%)$ & $0.27 \pm 0.04$ & $90 \pm 10.1$ & $(95.4 \%)$ & $337 \pm 37.7$ & $(35.6 \%)$ \\
\hline \multirow{6}{*}{$\begin{array}{l}0.1 \mathrm{M} \text { di-potassium } \\
\text { hydrogen phosphate }\end{array}$} & 5.8 & $5.4 \pm 0.51$ & $(26.9 \%)$ & $0.27 \pm 0.03$ & $22 \pm 1.8$ & $(23.5 \%)$ & $83 \pm 6.8$ & $(8.7 \%)$ \\
\hline & 6.0 & $5.1 \pm 0.40$ & $(25.8 \%)$ & $0.26 \pm 0.02$ & $18 \pm 0.4$ & $(20.0 \%)$ & $73 \pm 1.80$ & $(7.8 \%)$ \\
\hline & 6.5 & $5.2 \pm 0.22$ & $(26.0 \%)$ & $0.26 \pm 0.01$ & $23 \pm 0.4$ & $(24.6 \%)$ & $89 \pm 1.5$ & $(9.4 \%)$ \\
\hline & 7.0 & $4.6 \pm 0.45$ & $(22.8 \%)$ & $0.23 \pm 0.02$ & $18 \pm 0.8$ & $(19.6 \%)$ & $81 \pm 3.7$ & $(8.6 \%)$ \\
\hline & 7.5 & $4.9 \pm 0.28$ & $(24.5 \%)$ & $0.24 \pm 0.01$ & $17 \pm 0.4$ & $(18.6 \%)$ & $72 \pm 1.8$ & $(7.6 \%)$ \\
\hline & 8.0 & $4.6 \pm 0.28$ & $(22.8 \%)$ & $0.23 \pm 0.01$ & $19 \pm 1.0$ & $(20.5 \%)$ & $85 \pm 4.3$ & $(9.0 \%)$ \\
\hline \multirow{5}{*}{$\begin{array}{l}0.05 \mathrm{M} \text { Tri-sodium } \\
\text { borate, } 0.1 \mathrm{M} \mathrm{KCl}\end{array}$} & 8.0 & $7.6 \pm 0.76$ & $(38.0 \%)$ & $0.38 \pm 0.04$ & $38 \pm 4.6$ & $(40.6 \%)$ & $101 \pm 8.8$ & $(10.7 \%)$ \\
\hline & 8.5 & $7.2 \pm 1.04$ & $(36.1 \%)$ & $0.36 \pm 0.05$ & $39 \pm 2.8$ & $(41.4 \%)$ & $109 \pm 6.7$ & $(11.5 \%)$ \\
\hline & 9.0 & $7.3 \pm 0.79$ & $(36.7 \%)$ & $0.37 \pm 0.04$ & $39 \pm 1.0$ & $(41.7 \%)$ & $108 \pm 2.6$ & $(11.4 \%)$ \\
\hline & 9.5 & $7.4 \pm 0.89$ & $(36.9 \%)$ & $0.37 \pm 0.04$ & $39 \pm 0.4$ & $(41.2 \%)$ & $106 \pm 1.1$ & $(11.1 \%)$ \\
\hline & 10.0 & $6.6 \pm 0.41$ & $(33.2 \%)$ & $0.33 \pm 0.02$ & $41 \pm 6.6$ & $(43.0 \%)$ & $123 \pm 19.5$ & $(12.9 \%)$ \\
\hline \multirow{2}{*}{0.05 M Tris-glycine } & 8.5 & $5.9 \pm 0.24$ & $(29.5 \%)$ & $0.29 \pm 0.01$ & $82 \pm 5.1$ & $(86.7 \%)$ & $275 \pm 17.1$ & $(29.0 \%)$ \\
\hline & 9.0 & $5.5 \pm 0.17$ & $(27.7 \%)$ & $0.28 \pm 0.01$ & $88 \pm 6.5$ & $(92.7 \%)$ & $317 \pm 23.6$ & $(33.4 \%)$ \\
\hline \multirow{5}{*}{0.05 M Glycine } & 8.6 & $5.8 \pm 0.31$ & $(28.8 \%)$ & $0.29 \pm 0.01$ & $91 \pm 2.0$ & $(96.3 \%)$ & $317 \pm 6.2$ & $(33.4 \%)$ \\
\hline & 9.0 & $5.9 \pm 0.22$ & $(29.6 \%)$ & $0.30 \pm 0.01$ & $94 \pm 2.3$ & $(99.3 \%)$ & $318 \pm 24.9$ & $(33.5 \%)$ \\
\hline & 9.5 & $5.9 \pm 0.20$ & $(29.5 \%)$ & $0.29 \pm 0.01$ & $89 \pm 2.7$ & $(94.4 \%)$ & $303 \pm 7.9$ & $(32.0 \%)$ \\
\hline & 10.0 & $5.8 \pm 0.46$ & $(29.3 \%)$ & $0.29 \pm 0.02$ & $88 \pm 3.8$ & $(92.6 \%)$ & $300 \pm 12.9$ & $(31.6 \%)$ \\
\hline & 10.5 & $5.7 \pm 0.41$ & $(28.5 \%)$ & $0.28 \pm 0.02$ & $86 \pm 1.9$ & $(90.3 \%)$ & $300 \pm 5.8$ & $(31.7 \%)$ \\
\hline
\end{tabular}

In summary, considering the protein content, total and specific activity, the $0.05 \mathrm{M}$ glycine buffer $\mathrm{pH} 9.0$ was proposed as an optimized solution for the immobilization of papain on the matrix of both medium and high molecular weight chitosans (Tables 1 and 2), and this was the way the immobilized enzyme was further analyzed.

\subsection{Catalytic Properties of the Native and Immobilized Papain}

The immobilized papain was further investigated in order to characterize its stability and catalytic properties in comparison with the soluble enzyme. Optimal temperature and $\mathrm{pH}$ for papain immobilized on either medium or high molecular weight chitosans were similar to those of the soluble enzyme $\left(60^{\circ} \mathrm{C}\right.$ and 7.5 , respectively, see Figure 1$)$. With increasing $\mathrm{pH}$, the total activity of the enzyme immobilized on both chitosans decreased compared with the soluble one, apparently, due to their reduced solubility at high $\mathrm{pH}$ values. Further, at $80{ }^{\circ} \mathrm{C}$ free enzymatic activity reduced by $68 \%$ of its initial value, while complete inactivation could be observed at $90^{\circ} \mathrm{C}$ (Figure 1b). By contrast, the papain immobilized on either medium or high molecular weight chitosans retained $80 \%$ and $98 \%$ at $80{ }^{\circ} \mathrm{C}$, as well as $45 \%$ and $57 \%$ of their initial activity at $90{ }^{\circ} \mathrm{C}$, respectively (Figure $1 \mathrm{~b}$ ). Of note, neither total nor specific activities of the enzyme immobilized on both chitosans decreased at low temperatures. These data suggest that adsorption on chitosan alternates neither optimal temperature nor $\mathrm{pH}$, while increasing the thermal stability of papain, apparently due to the restricted conformational flexibility of the protein, thereby preventing its premature denaturation. 
Table 2. The effect of buffers on papain adsorption on high molecular weight chitosan from solution. In brackets, bound total protein, total and specific activities are shown as the percentage of their initial values, respectively.

\begin{tabular}{|c|c|c|c|c|c|c|c|c|}
\hline \multirow{5}{*}{$\begin{array}{c}\text { Buffer System } \\
0.2 \text { M Sodium acetate }\end{array}$} & \multirow{2}{*}{$\begin{array}{l}\mathbf{p H} \\
4.0\end{array}$} & \multicolumn{2}{|c|}{$\begin{array}{c}\text { Total Protein, } \\
\text { mg g Chitosan }^{-1}\end{array}$} & \multirow{2}{*}{$\begin{array}{c}\text { Protein, } \mathbf{m g ~ m L}^{-\mathbf{1}} \\
0.17 \pm 0.03\end{array}$} & \multicolumn{2}{|c|}{ Activity, $\mathrm{U} \mathrm{mL}^{-1}$} & \multicolumn{2}{|c|}{$\begin{array}{l}\text { Specific Activity, } \\
\text { U mg Protein }{ }^{-1}\end{array}$} \\
\hline & & $3.4 \pm 0.63$ & $(16.8 \%)$ & & $46 \pm 8.8$ & $(48.0 \%)$ & $271 \pm 52.3$ & $(28.6 \%)$ \\
\hline & 4.5 & $4.7 \pm 0.33$ & $(21.3 \%)$ & $0.21 \pm 0.02$ & $50 \pm 8.4$ & $(52.8 \%)$ & $235 \pm 39.5$ & $(24.8 \%)$ \\
\hline & 5.0 & $6.9 \pm 0.69$ & $(34.4 \%)$ & $0.34 \pm 0.04$ & $88 \pm 4.6$ & $(93.4 \%)$ & $257 \pm 13.3$ & $(27.1 \%)$ \\
\hline & 5.8 & $7.1 \pm 0.89$ & $(35.7 \%)$ & $0.36 \pm 0.05$ & $78 \pm 8.4$ & $(82.0 \%)$ & $218 \pm 23.7$ & $(23.0 \%)$ \\
\hline \multirow{6}{*}{$\begin{array}{l}0.1 \mathrm{M} \text { di-potassium } \\
\text { hydrogen phosphate }\end{array}$} & 5.8 & $5.7 \pm 0.64$ & $(28.3 \%)$ & $0.28 \pm 0.03$ & $26 \pm 2.4$ & $(27.7 \%)$ & $92 \pm 5.3$ & $(9.8 \%)$ \\
\hline & 6.0 & $5.3 \pm 0.54$ & $(26.5 \%)$ & $0.26 \pm 0.03$ & $27 \pm 2.0$ & $(28.5 \%)$ & $102 \pm 7.6$ & $(10.7 \%)$ \\
\hline & 6.5 & $5.0 \pm 0.33$ & $(25.4 \%)$ & $0.25 \pm 0.01$ & $27 \pm 2.1$ & $(28.6 \%)$ & $107 \pm 6.7$ & $(11.3 \%)$ \\
\hline & 7.0 & $4.7 \pm 0.74$ & $(23.4 \%)$ & $0.23 \pm 0.02$ & $25 \pm 1.8$ & $(26.9 \%)$ & $109 \pm 5.6$ & $(11.6 \%)$ \\
\hline & 7.5 & $4.3 \pm 0.47$ & $(21.4 \%)$ & $0.21 \pm 0.02$ & $25 \pm 1.4$ & $(26.4 \%)$ & $117 \pm 8.2$ & $(12.3 \%)$ \\
\hline & 8.0 & $4.2 \pm 0.35$ & $(21.1 \%)$ & $0.21 \pm 0.01$ & $24 \pm 1.3$ & $(25.7 \%)$ & $114 \pm 10.0$ & $(12.0 \%)$ \\
\hline \multirow{5}{*}{$\begin{array}{l}0.05 \mathrm{M} \text { Tri-sodium } \\
\text { borate, } 0.1 \mathrm{M} \mathrm{KCl}\end{array}$} & 8.0 & $8.2 \pm 0.68$ & $(41.3 \%)$ & $0.41 \pm 0.03$ & $94 \pm 5.1$ & $(99.6 \%)$ & $229 \pm 8.3$ & $(24.1 \%)$ \\
\hline & 8.5 & $7.9 \pm 1.19$ & $(39.7 \%)$ & $0.40 \pm 0.06$ & $93 \pm 6.4$ & $(98.7 \%)$ & $235 \pm 16.1$ & $(24.8 \%)$ \\
\hline & 9.0 & $7.5 \pm 0.73$ & $(37.6 \%)$ & $0.38 \pm 0.04$ & $93 \pm 3.8$ & $(98.8 \%)$ & $249 \pm 10.2$ & $(26.3 \%)$ \\
\hline & 9.5 & $6.2 \pm 1.91$ & $(30.1 \%)$ & $0.31 \pm 0.09$ & $94 \pm 3.2$ & $(99.6 \%)$ & $305 \pm 10.4$ & $(21.2 \%)$ \\
\hline & 10.0 & $5.9 \pm 1.08$ & $(29.4 \%)$ & $0.29 \pm 0.05$ & $94 \pm 5.3$ & $(99.1 \%)$ & $319 \pm 10.1$ & $(33.7 \%)$ \\
\hline \multirow{2}{*}{0.05 M Tris-glycine } & 8.5 & $8.4 \pm 1.5$ & $(42.2 \%)$ & $0.42 \pm 0.08$ & $92 \pm 6.9$ & $(97.4 \%)$ & $219 \pm 16.3$ & $(23.1 \%)$ \\
\hline & 9.0 & $7.2 \pm 0.8$ & $(36.2 \%)$ & $0.36 \pm 0.04$ & $91 \pm 5.2$ & $(96.6 \%)$ & $253 \pm 14.3$ & $(26.7 \%)$ \\
\hline \multirow{5}{*}{0.05 M Glycine } & 8.6 & $7.0 \pm 0.6$ & $(35.1 \%)$ & $0.35 \pm 0.03$ & $86 \pm 5.2$ & $(91.1 \%)$ & $246 \pm 10.4$ & $(26.0 \%)$ \\
\hline & 9.0 & $7.2 \pm 1.04$ & $(36.0 \%)$ & $0.36 \pm 0.05$ & $94 \pm 7.9$ & $(99.8 \%)$ & $263 \pm 15.3$ & $(27.7 \%)$ \\
\hline & 9.5 & $8.2 \pm 0.47$ & $(40.9 \%)$ & $0.41 \pm 0.02$ & $94 \pm 4.2$ & $(99.5 \%)$ & $231 \pm 9.6$ & $(24.3 \%)$ \\
\hline & 10.0 & $8.1 \pm 0.9$ & $(40.7 \%)$ & $0.41 \pm 0.05$ & $94 \pm 5.7$ & $(99.0 \%)$ & $230 \pm 11.7$ & $(24.3 \%)$ \\
\hline & 10.5 & $7.9 \pm 1.2$ & $(39.7 \%)$ & $0.39 \pm 0.06$ & $93 \pm 9.7$ & $(98.3 \%)$ & $235 \pm 24.4$ & $(24.8 \%)$ \\
\hline
\end{tabular}

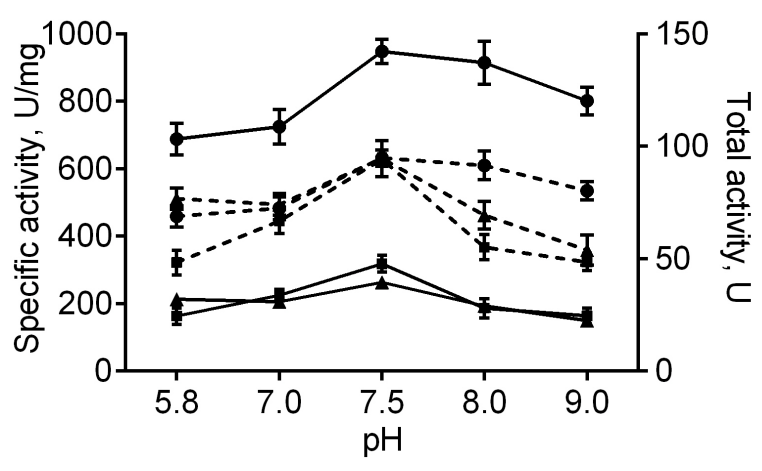

(a)

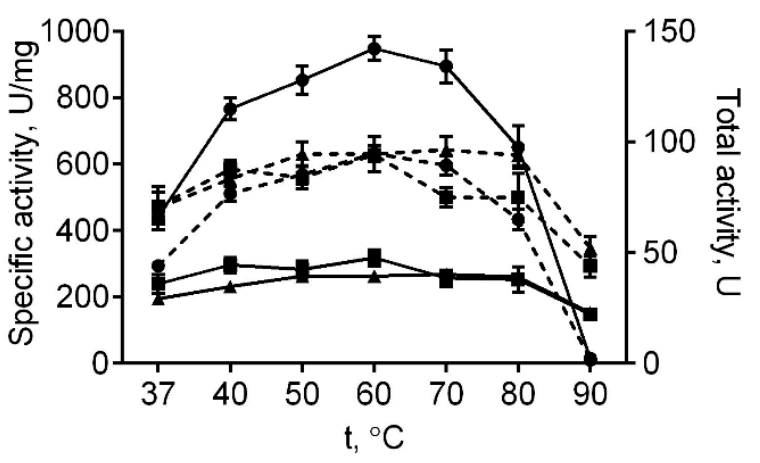

(b)

Figure 1. The $\mathrm{pH}(\mathbf{a})$ and temperature (b) dependencies of the total (dashed lines) and specific activities (solid lines) of the soluble papain (circles), as well as the enzyme immobilized on either medium molecular weight (squares) or high molecular weight chitosan (triangles).

Long-term stability of both free and immobilized papain in various solutions were also tested. For that, both enzymes were incubated at $37^{\circ} \mathrm{C}$ in $50 \mathrm{mM}$ Tris buffer $\mathrm{pH}$ 7.5. The half-life of soluble papain was approximately three days, while the remaining activity of papain immobilized on both types of chitosans was about $93 \%$ and $83 \%$ of the initial values after three and seven days, respectively (Figure 2a). The extrapolated half-life times were found to be $78 \pm 0.7 \mathrm{~h}, 520 \pm 0.7 \mathrm{~h}$, and $441 \pm 1.4 \mathrm{~h}$ for soluble, immobilized on medium molecular weight chitosans, and immobilized on high molecular weight 
chitosans, respectively. Further, the stabilization factor (SF) (the half-life's ratio of soluble and immobilized enzyme) was estimated as 6.67 for the medium and 5.65 for the high molecular weight chitosans, respectively.

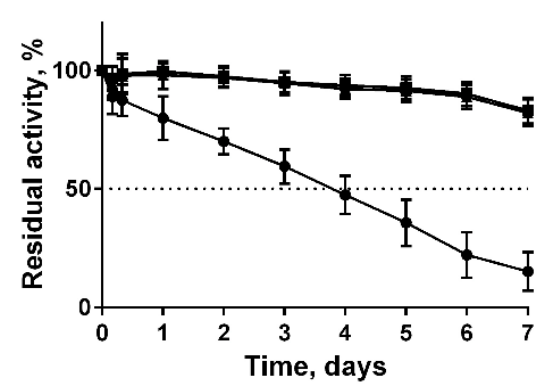

(a)

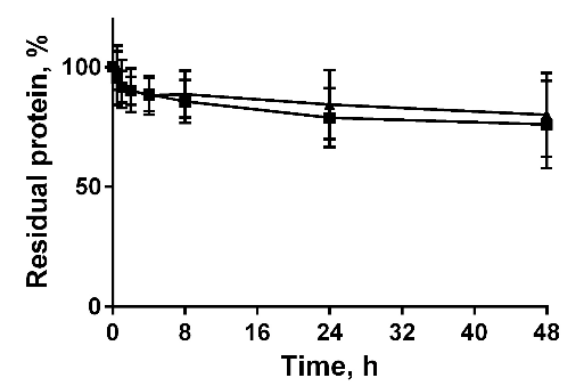

(b)

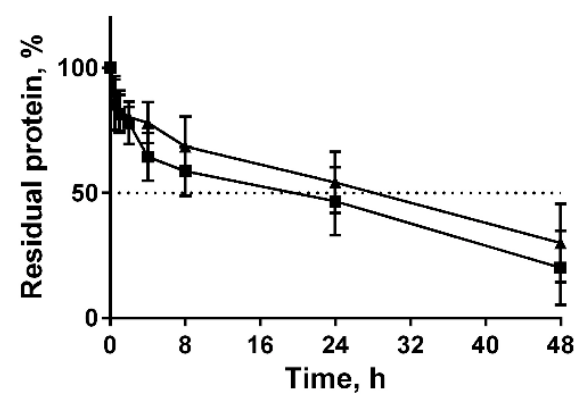

(c)

Figure 2. Enzymatic stability of soluble papain (circles) and enzyme immobilized on either medium molecular weight (squares) or high molecular weight chitosan (triangles) when stored at $37^{\circ} \mathrm{C}$ in $50 \mathrm{mM}$ Tris buffer pH 7.5 (a); desorption of papain immobilized on either medium molecular weight (squares) or high molecular weight chitosan (triangles) at $37^{\circ} \mathrm{C}$ in either $50 \mathrm{mM}$ Tris buffer $\mathrm{pH} 7.5$ (b) or in $0.9 \% \mathrm{NaCl}$ (c).

Since the enzyme did not bind covalently to the carrier, one could expect the dissociation of the complex while being in solutions. The desorption of papain from both chitosans in $50 \mathrm{mM}$ Tris- $\mathrm{HCl}$ pH 7.5 after $48 \mathrm{~h}$ of incubation did not exceed $24 \%$ (Figure 2b). By contrast, in physiological saline $(0.9 \% \mathrm{NaCl})$ approximately $50 \%$ of protein dissociated into solution in $24 \mathrm{~h}$, and $75 \%$ of protein was desorbed in $48 \mathrm{~h}$ (Figure $2 \mathrm{c}$ ).

Generally, immobilization of the enzyme on insoluble carriers changes the kinetic parameters of enzymatic catalysis. Therefore, the apparent maximum steady-state rate $\left(\mathrm{V}_{\max }\right)$, the apparent Michaelis constant $\left(\mathrm{K}_{\mathrm{m}}\right)$, and apparent catalytic constant $\left(\mathrm{k}_{\mathrm{cat}}\right)$ values of the immobilized and free papain were calculated (Table 3, Figure 3). As one can see from Table 3 , immobilization on both chitosans did not change the $K_{m}$ of papain, suggesting no changes in the enzymatic affinity to substrate. By contrast, a 3-fold decrease in $V_{\max }$ and 8-12-fold decrease in $\mathrm{k}_{\text {cat }}$ values was observed, suggesting the repression of the catalyst, apparently as the consequence of conformational restrictions due to immobilization.

Table 3. Kinetic constants of soluble and immobilized papain.

\begin{tabular}{|c|c|c|c|c|c|}
\hline Sample & $\mathbf{K}_{\mathrm{m}}, \mu \mathrm{M}$ & 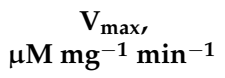 & $\begin{array}{c}k_{\text {cat }} \\
\min ^{-1}\end{array}$ & $\mathrm{~V}_{\max } / K_{\mathrm{m}}$ & $\mathbf{k}_{\text {cat }} / K_{\mathrm{m}}$ \\
\hline Soluble papain & $22.3 \pm 3.5$ & $1253 \pm 64$ & $57.8 \pm 2.9$ & 56.2 & 2.59 \\
\hline Medium molecular weight chitosan immobilized papain & $24.7 \pm 5.4$ & $432 \pm 32$ & $6.8 \pm 0.5$ & 17.3 & 0.28 \\
\hline High molecular weight chitosan immobilized papain & $23.1 \pm 4.3$ & $349 \pm 21$ & $4.5 \pm 0.3$ & 15.2 & 0.19 \\
\hline
\end{tabular}

\subsection{Anti-Biofilm Properties of Immobilized Papain}

Various proteases have been reported to disrupt microbial biofilms on wound surfaces $[47,48]$ including the papain $[9,11,12]$. Therefore, the ability of chitosan-immobilized papain to disrupt the bacterial biofilms was assessed. For that, $48 \mathrm{~h}$ old biofilms were grown on 24-well plates and washed twice, followed by incubation in fresh BM broth supplemented by papain $\left(1 \mathrm{mg} \mathrm{mL} \mathrm{mL}^{-1}\right)$ for $24 \mathrm{~h}$, as previously indicated for immobilized ficin [49]. After $24 \mathrm{~h}$, the residual biofilms were subjected to crystal violet staining. Trypsin, a protease that is commonly used for wound treatment [50], and ficin with confirmed anti-biofilm activity [51] served as references. Soluble papain destroyed biofilms formed by Staphylococci and Micrococcus luteus, although it appeared less efficient compared with ficin (See Figure 4). In contrast, neither for Bacillus cereus nor for the Gram-negative bacteria could a similar effect be observed. Taking into account the significant medical relevance of 
Staphylococci on topical wounds, the anti-biofilm activity of the immobilized papain was further tested on solely staphylococcal biofilms. The immobilized papain samples were added until final concentrations corresponded to soluble papain solutions with either 10, 100 , and $500 \mu \mathrm{g}$ protein $\mathrm{mL}^{-1}$, while the same amounts of chitosan alone were tested as a control $\left(1.4,14.0\right.$, and $70 \mathrm{mg} \mathrm{mL}^{-1}$ for the medium molecular weight chitosan and 1.7, 17.0, and 85.0 for the high molecular weight chitosan, respectively). Pure papain reduced the biofilm biomass of both S. aureus and S. epidermidis twice at the concentration of $500 \mu \mathrm{g}$ protein $\mathrm{mL}^{-1}$. Both medium and high molecular weight chitosans themselves also decreased the biofilm biomass at low concentrations (1.4-17 $\left.\mathrm{mg} \mathrm{mL}^{-1}\right)$, apparently due to the mechanical removal of the biofilm (Figure 5b,d). At high concentrations, chitosan clumps remained adherent to the plate surface, leading to the artificial increase of retained dye. Therefore, the decrease of the biofilm biomass in wells treated with immobilized papain was compared with the biofilms in wells treated with the same amount of pure chitosan (compare Figure 5b,c; Figure 5d,e). After treatment with medium molecular weight chitosan immobilized papain in amounts corresponding to $100 \mu \mathrm{g} \mathrm{mL}^{-1}$ of the protein, the biofilm biomass of both Staphylococci decreased by $25 \%$, similar to the effect of the soluble enzyme (compare Figure 5a,c). Higher concentrations did not lead to the biofilm destruction, apparently because of the chitosan adhesion to the plate. Papain immobilized on high molecular weight chitosan exhibited similar effects only on S. aureus, while only moderate suppression of the S. epidermidis biofilm (which did not lead to statistically significant differences) could be observed.

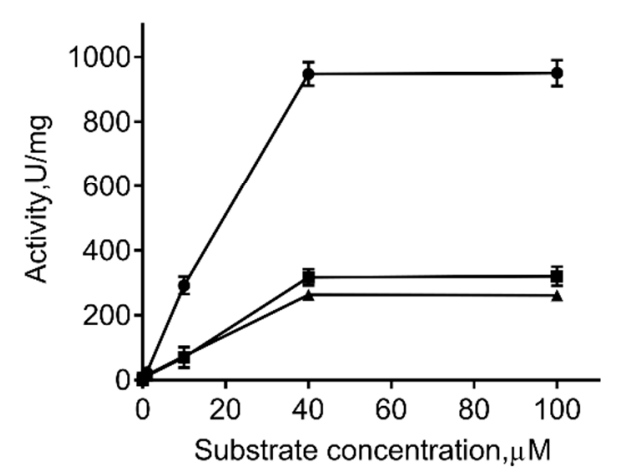

(a)

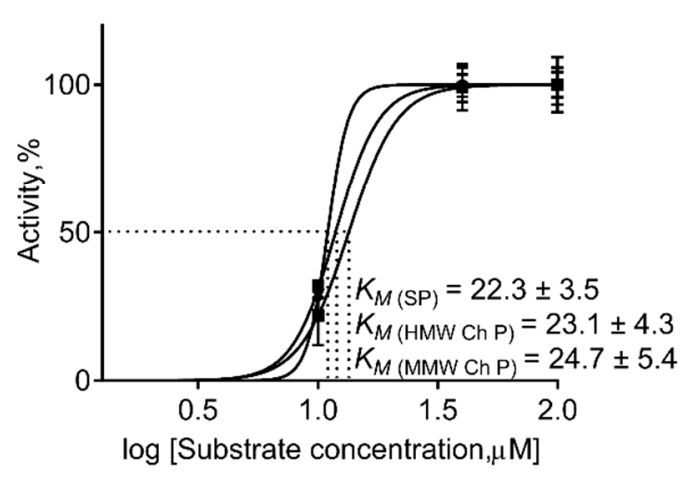

(b)

Figure 3. The effect of substrate concentration on activities of soluble papain (SP, circles) and enzyme immobilized on either medium molecular weight (MMW Ch P, squares) or high molecular weight chitosan (HMW Ch $\mathrm{P}$, triangles) (a). Calculation of substrate concentration providing the half-maximal activity of enzymes $\left(\mathrm{K}_{\mathrm{m}}\right)(\mathbf{b})$.

\subsection{Increasing the Efficiency of Antimicrobials Against Staphylococcal Biofilms by Soluble and Citosan-Immobilized Papain}

While embedded into the matrix of the biofilm, bacterial cells become inaccessible to both antibiotics and biocides. The above data suggest that chitosan-immobilized papain could increase the efficiency of antimicrobials against biofilm-embedded bacteria by destroying the biofilm structure, as had been shown previously in other model investigations [48,49]. To test the above hypothesis, next $48 \mathrm{~h}$ old biofilms were incubated for $24 \mathrm{~h}$ in the presence of papain (either soluble or immobilized on chitosans with the final protein concentration of $100 \mu \mathrm{g}$ protein $\mathrm{mL}^{-1}$ ) and antimicrobials at their respective $4 \times$ MBCs (minimal bactericidal concentrations, see Table 4 for values). After incubation, the plates were washed twice by sterile PBS to remove residual planktonic and detached cells and quantified by counting CFUs (see Section 5. Materials and Methods). 
S. aureus

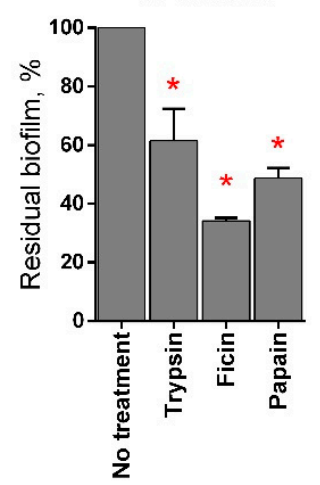

B. cereus

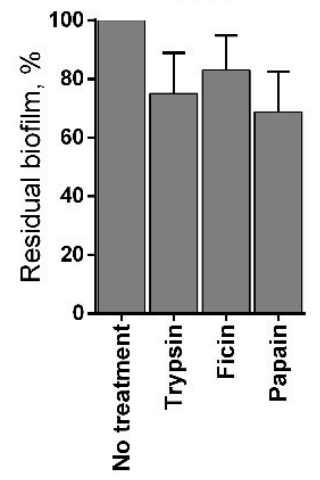

S. epidermidis

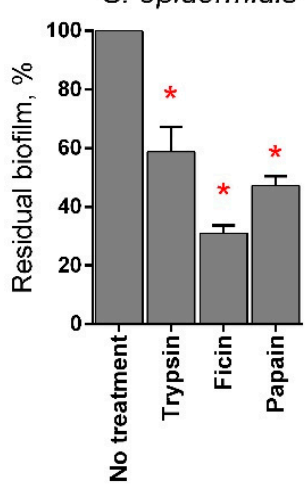

E. coli

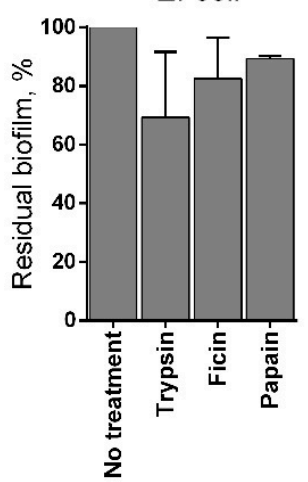

M. luteus

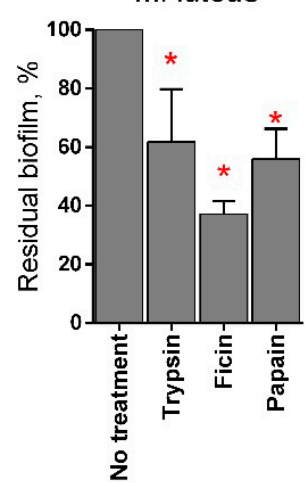

$P$. aeruginosa

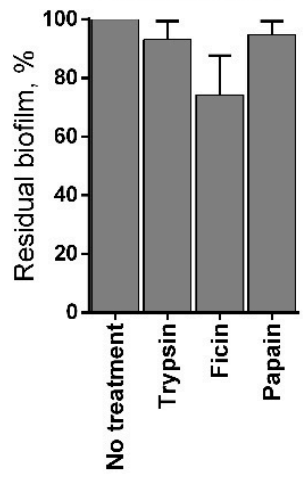

Figure 4. The effects of trypsin, ficin, and papain on bacterial biofilms. The $48 \mathrm{~h}$ old biofilms were gently washed by BM broth and loaded with fresh BM broth supplemented with trypsin, ficin, and papain at concentration of $1 \mathrm{mg} \cdot \mathrm{mL}^{-1}$. After $24 \mathrm{~h}$ incubation, biofilms were assessed by crystal-violet staining. Asterisks $\left(^{*}\right)$ denote statistically significant difference between treated and untreated wells $(p<0.05)$.

Table 4. Minimum Inhibitory Concentration (MIC) and Minimal Bactericidal Concentrations (MBC) values of antimicrobials.

\begin{tabular}{ccccc}
\hline & \multicolumn{2}{c}{ S. aureus } & \multicolumn{2}{c}{ S. epidermidis } \\
\hline & $\mathrm{MIC}, \mu \mathrm{gL}^{-1}$ & $\mathrm{MBC}, \mu \mathrm{gL}^{-1}$ & $\mathrm{MIC}, \mu \mathrm{gL}^{-1}$ & $\mathrm{MBC}_{\mu} \mu \mathrm{g} \mathrm{mL}^{-1}$ \\
\hline Gentamycin & 4 & 16 & 1 & 4 \\
\hline Ciprofloxacin & 2 & 32 & 0.5 & 4 \\
\hline Benzalkonium chloride & 1 & 16 & 1 & 4 \\
\hline
\end{tabular}

The efficiency of solely ciprofloxacin and gentamicin against cells in biofilms was low, apparently because of the protective properties of the biofilm (Figure 6, compare control and black bars). Benzalkonium chloride was able to reduce CFUs amount by 2 orders of magnitude. As can be seen from (Figure 6a,b), the combination of all antimicrobials with enzyme immobilized on medium molecular weight chitosan (bars labeled as PCh) led to a significant decrease in the number of CFUs (by approximately 3-4 orders of magnitude) in biofilms of both Staphylococci, similar to the samples treated with soluble papain (bars labeled by P). Of note, a significantly pronounced drop of viable cell count was observed when combining benzalkonium chloride with immobilized papain. Unexpectedly, the combination of all antimicrobials with papain immobilized on high molecular weight chitosan did not enhance the efficiency of antimicrobials against biofilm-embedded $S$. aureus (Figure 6c), while the anti-biofilm effect could be observed for ciprofloxacin and gentamicin against $S$. epidermidis even with pure chitosan (Figure 6d). Apparently, this effect could be attributed to the mechanical removal of the biofilm by high molecular weight chitosan particles. 
A
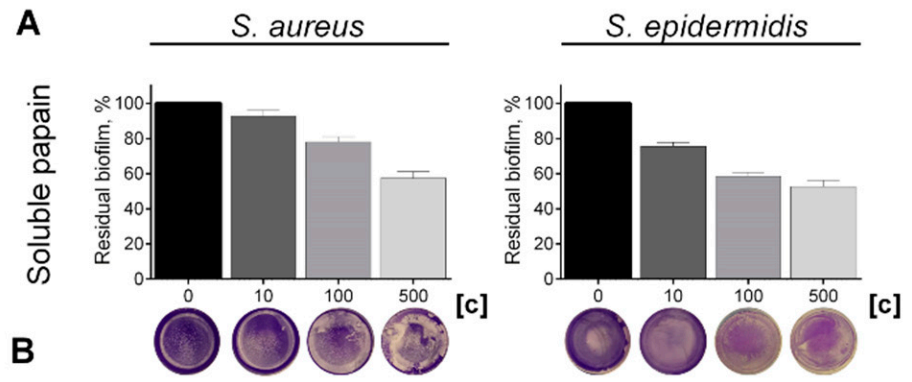

B

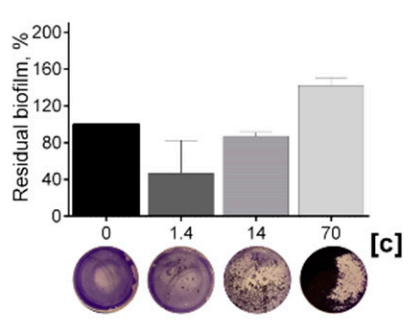

C
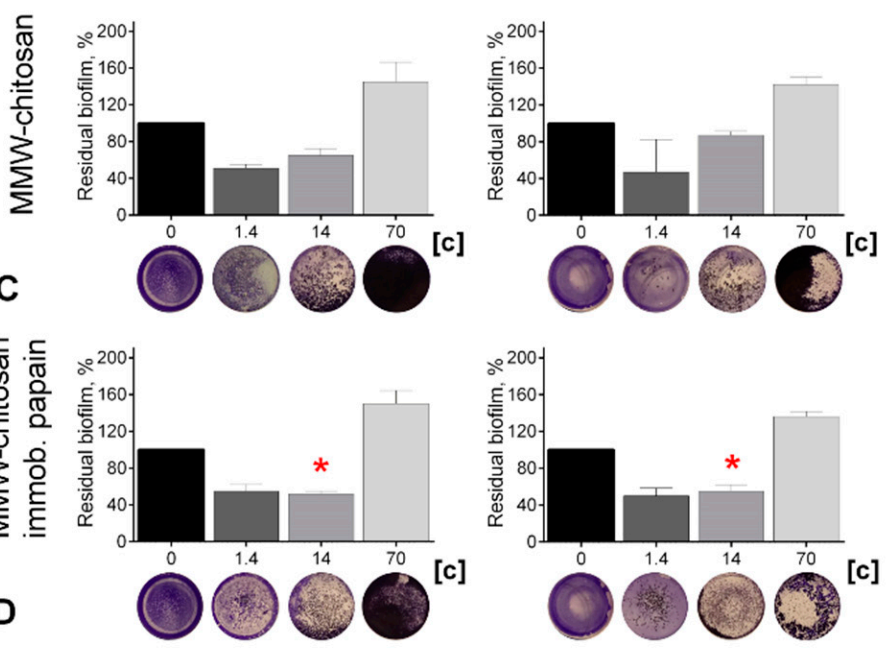

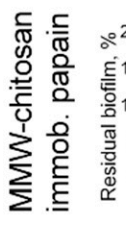
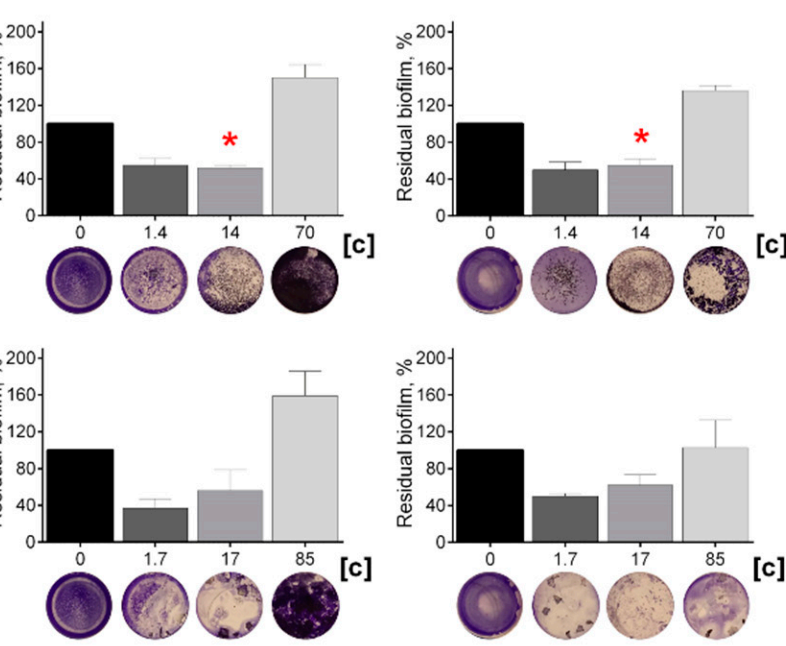

E
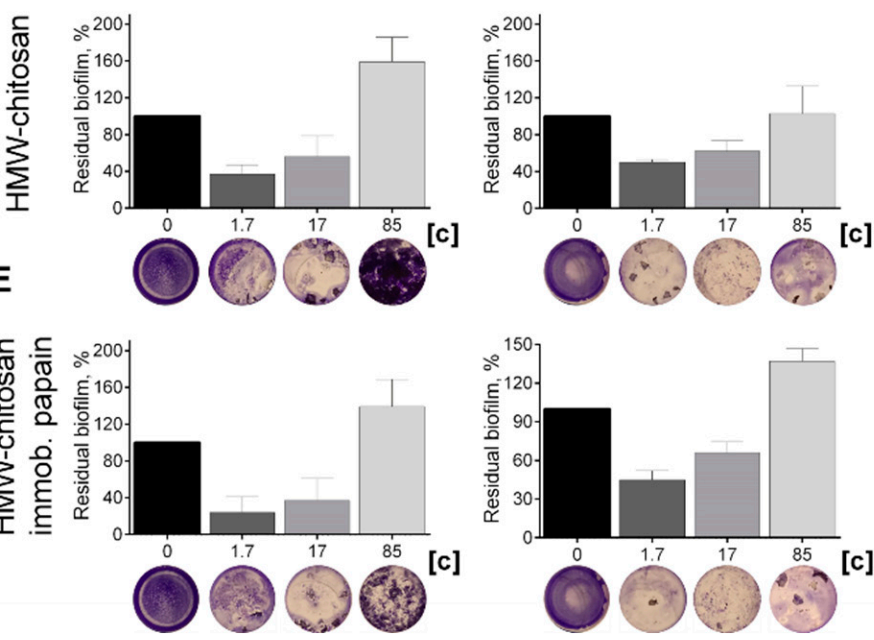

Figure 5. The effect of (A) soluble, (C) medium- and (E) high molecular weight chitosan-immobilized papain as well as solely (B) medium- and (D) high molecular weight chitosans on S. aureus and S. epidermidis biofilms. The $48 \mathrm{~h}$ old biofilms were gently washed by BM broth and loaded with fresh BM broth supplemented with substances as indicated. Soluble papain concentrations were 10, 100 , or $500 \mu \mathrm{g} \cdot \mathrm{mL}^{-1}$. Papain immobilized on medium molecular weight chitosan was added until final concentrations of $1.4,14$, or $70 \mathrm{mg} \cdot \mathrm{mL}^{-1}$ (corresponding to the same final papain concentration by the total protein), respectively. Papain immobilized on high molecular weight chitosan was added at concentrations of $1.7,17$, or $85 \mathrm{mg} \cdot \mathrm{mL}^{-1}$, respectively. Incubation was followed for $24 \mathrm{~h}$ and residual biofilms were quantified by crystal-violet staining. Asterisks $\left({ }^{*}\right)$ denote statistically significant difference between samples treated with either pure chitosan or chitosan with immobilized papain $(p<0.05)$. Untreated wells were considered as $100 \%$. 
Medium molecular weight Chitosan

A

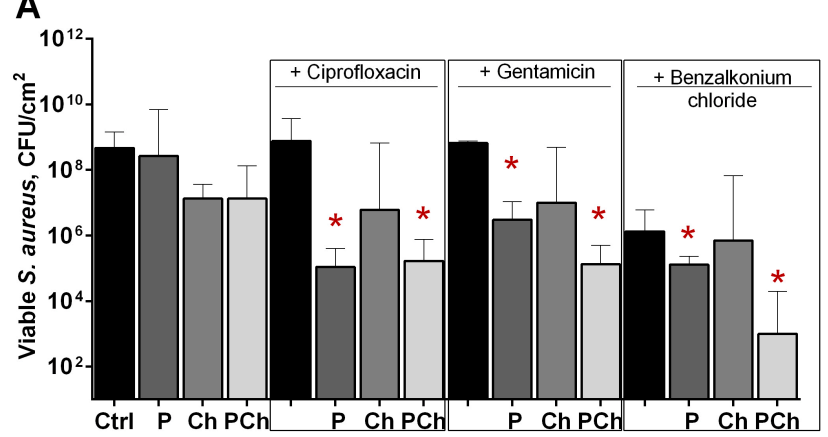

B

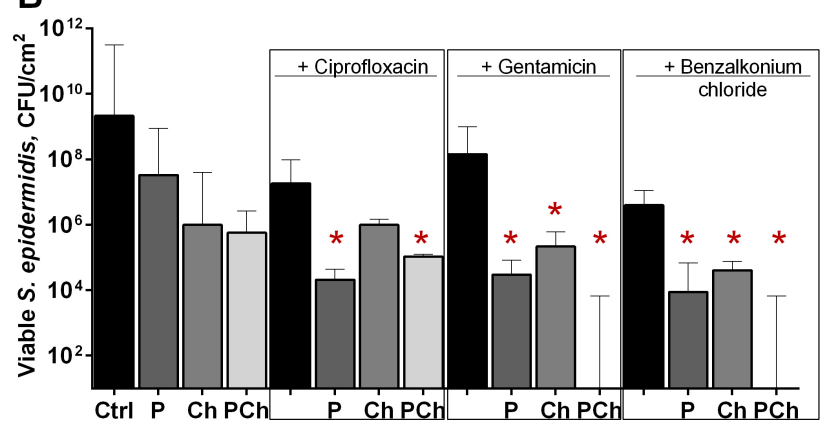

High molecular weight Chitosan

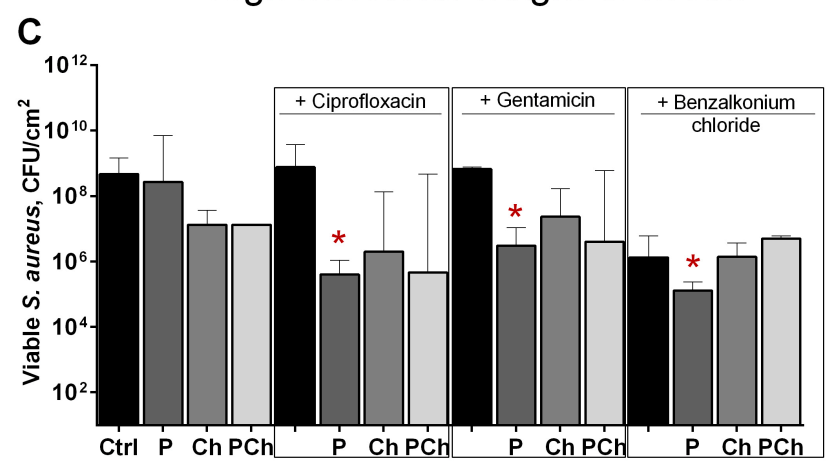

D

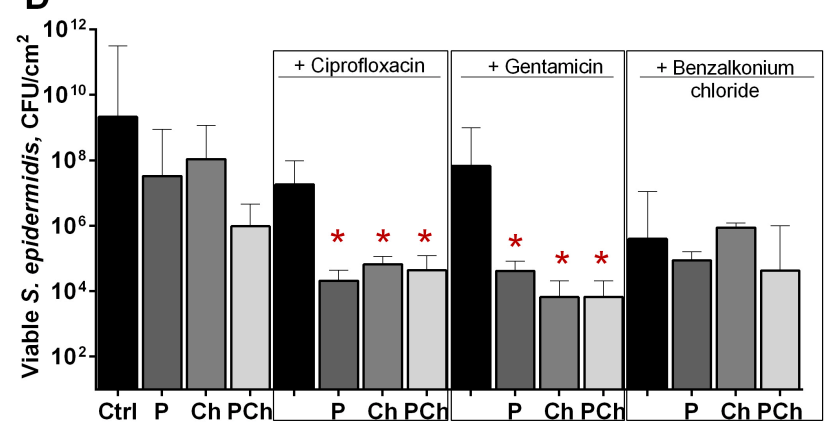

Figure 6. The effect of soluble (P), (A,B) medium- and (C,D) high molecular weight chitosan-immobilized papain (PCh) as well as solely (A,B) medium- and (C,D) high molecular weight chitosans (Ch) on susceptibility of biofilms-embedded S. aureus and S. epidermidis to antimicrobials. Soluble or immobilized on either medium or high molecular weight chitosan papain was added to $48 \mathrm{~h}$ old biofilms until final concentrations of $500 \mu \mathrm{g} \cdot \mathrm{mL}^{-1}, 70 \mathrm{mg} \cdot \mathrm{mL}^{-1}, 85 \mathrm{mg} \cdot \mathrm{mL}^{-1}$, respectively (similar total protein). Chitosans were added until $70 \mathrm{mg} \cdot \mathrm{mL}^{-1}$ and $85 \mathrm{mg} \cdot \mathrm{mL}^{-1}$, respectively. Ciprofloxacin, gentamicin, or benzalkonium chloride were added up to final concentrations of $8 \times \mathrm{MBC}$ (see Table 4 for values). After $24 \mathrm{~h}$ incubation, the biofilms were washed twice with sterile $0.9 \% \mathrm{NaCl}$. The adherent cells were scratched, resuspended, and their viability was analyzed by CFUs count. Asterisks $\left(^{*}\right)$ denote statistically significant difference of residual CFUs in control wells (solely antimicrobials) and wells with combined treatment $(p<0.05)$.

\section{Discussion}

Papain, a non-specific sulfhydryl protease from the latex of Carica papaya, was intensively investigated as a promising enzyme for the food industry (for meat tenderization and production of protein hydrolysates), biotechnology (for bioactive peptides production), as well as medicine (as an anti-inflammatory, wound debriding, and healing agent) $[52,53]$. While effectively degrading necrotic tissues, papain does not affect healthy tissues due to its inactivation by $\alpha 1$-antitrypsin, which makes papain an attractive wound healing agent. Thus, in several studies papain-containing gels were reported as effective agents for venous ulcers healing, which can be safely used in granulation tissue [54-56].

Here we report the immobilization of papain on both medium and high molecular weight chitosan, as well as anti-biofilm properties of the immobilized enzyme. Chitosans, being natural polymers, exhibit broad-spectrum antimicrobial properties and are characterized by low toxicity on the one hand $[57,58]$, while having great potential as an enzyme immobilization carrier on the other hand [59-61]. The developed approach for the adsorption-based immobilization of papain on matrixes of either medium or high molecular weight chitosans allowed coupling of up to $30 \%$ of the total protein $\left(\mathrm{mg} \mathrm{g}_{\text { chitosan }}{ }^{-1}\right)$ and specific activity ( $\mathrm{U}$ mg protein ${ }^{-1}$ ), as well as above $90 \%$ of the initial total activity ( $\mathrm{U} \mathrm{mL}^{-1}$ ) measured by using azocasein as a substrate (see Tables 1 and 2). Of note, the maximal adsorption of papain could be achieved at $\mathrm{pH}$ 9.0. Under these conditions, chitosan loses the charge [62], suggesting that the mechanism of immobilization is rather governed by 
hydrophobic adsorption than by ionic interactions. Nevertheless, the particular underlying mechanism is still not completely clear and requires further detailed investigations.

The conformational changes observed during substrate-enzyme interactions and required for the catalytic act are determined by both preexisting conformations (conformational selection), as well as self-induced changes of the substrate on the enzyme conformation (induced fit) $[63,64]$. By contrast, immobilization increases the structural rigidity of the enzyme with the formation of more enzyme-support stable bonds. While the spacer arms are short enough and the support is rigid $[65,66]$, this in turn leads to lower flexibility of the protein chain and consequently lower catalytic efficiency and specificity [63]. Immobilization on chitosans did not affect the $\mathrm{K}_{\mathrm{m}}$ of papain, while $\mathrm{V}_{\max }$ decreased 3-fold (Table 3, Figure 3), apparently, because of the limited flexibility of the enzyme molecule fixed on the surface of chitosan. Similar explanation could be proposed for the increased thermostability of the immobilized enzyme. Thus, the immobilized papain lost only onehalf of its initial activity at $90^{\circ} \mathrm{C}$, while the soluble enzyme was completely inactivated (Figure 2). Next, while being stored in a buffer at $37^{\circ} \mathrm{C}$, the activity of pure enzyme was inactivated by $50 \%$ in 3.3 days, while immobilized papain maintained $83 \%$ of its initial activity even after 7 days (Figure 2a) with an extrapolated half-inactivation time of about 22 days for the medium and 18 days for the high molecular weight chitosans, respectively, under conditions tested.

The obvious disadvantage of the adsorption-based immobilization could be fast desorption of the enzyme in solutions with even low ionic strength. Thus, in $0.9 \% \mathrm{NaCl}$ half of the protein detached from the carrier in $24 \mathrm{~h}$ (Figure 2c). From the other side, this property could be used for wound-dressing materials design with dosed release of the enzyme to overcome relatively high cytotoxicity of the soluble papain, similar to enzyme loading into nanospheres, since the $\mathrm{CC}_{50}$ of papain has been reported to range from 6 to $260 \mu \mathrm{g} \mathrm{mL}{ }^{-1}$ on various cell lines [12,67-69].

Besides wound debridement and healing applications, papain-gel with a red-light absorbing pigment (methylene blue-MB) has been proposed for the eradication of Streptococcus mutans biofilms [70]. The biofilm formation on chronic and acute wounds is an important factor that strongly affects their healing and prevents wound closure [71]. Being in the biofilm, bacteria are embedded into a self-produced extracellular matrix of organic polymers $[72,73]$ that drastically reduces their susceptibility to antimicrobial treatment $[74,75]$. Our results indicate that papain itself efficiently degrades the structural components of the biofilm matrixes formed by S. aureus, S. epidermidis, M. luteus, including a substantial fraction of proteins [76]. In turn, being added at the same concentrations of $1 \mathrm{mg} \mathrm{mL}^{-1}$, papain led to a deeper destruction of the biofilms compared with trypsin, a protease that is widely used in wound treatment [50], although papain was less efficient than ficin (Figure 4). By contrast, only a weak effect of all proteases was observed against biofilms formed by Pseudomonas aeruginosa, Escherichia coli, and B. cereus (see Figure 4), apparently because their biofilm matrixes consist mainly of eDNA and polysaccharides [77]. Unfortunately, artificially high values were obtained in crystal violet staining of biofilms treated with high concentration of chitosans (solely or with immobilized papain) (Figure 5), while the photographs of plate bottoms treated with immobilized enzyme lacked the blue color corresponding to the biofilm stain (compare treated and control wells), suggesting removal of the biofilm. Less pronounced decrease of the blue stain was also observed in the wells treated solely by chitosan, apparently because of the mechanical scratching of the biofilm. Indeed, both medium and high molecular weight chitosans (solely or immobilized with papain) at concentrations of 14 and $17 \mathrm{mg} \mathrm{mL}^{-1}$, respectively, decreased the CFUs number of Staphylococci in the biofilm 10-fold (Figure 6), while the soluble enzyme led to a less pronounced drop of the adherent cells count. By contrast, only soluble papain and enzyme immobilized on medium molecular weight chitosan potentiated the efficacy of antimicrobials against biofilm-embedded S. aureus cells (Figure 6a,c). No statistically significant differences were observed between samples treated with any of the tested antimicrobial either in the presence or in the absence of either chitosans or papain immobilized on 
high molecular weight chitosan, suggesting the leading role of the enzymatic degradation of the biofilm in comparison with the mechanical destruction of $S$. aureus biofilms. Interestingly, this effect was not relevant for S. epidermidis, where the mechanical destruction of the biofilm also increased the efficacy of antimicrobials against biofilm embedded cells, although the combination of enzyme immobilized on medium molecular weight chitosan with either gentamicin or benzalkonium chloride led to almost complete eradication of the biofilm. This effect could be due to the differences in the biofilm structures formed by $S$. aureus and S. epidermidis and, consequently, their different permeabilities [78,79].

Thus, papain, either soluble or immobilized on medium molecular weight chitosan appears to be a beneficial agent for outer wound treatment capable of biofilms destruction, increasing the efficacy of antimicrobial treatment. The particular wound healing activity of both soluble and immobilized enzymes requires further investigation.

\section{Conclusions}

Thus, papain, either soluble or immobilized on medium molecular weight chitosan, efficiently destroys biofilms formed by $S$. aureus and $S$. epidermidis and potentiates the efficacy of antimicrobial treatment of biofilm-embedded Staphylococci. Moreover, while the adsorption-based immobilization of papain on chitosan leads to fast desorption of the enzyme in solutions, this property could be beneficial for wound-dressing materials design with dosed release of the enzyme to overcome relatively high cytotoxicity of the soluble papain. Taken together, our data indicate that papain immobilized on medium molecular weight chitosan appears a beneficial agent for outer wound treatment capable of the biofilms destruction, increasing the efficacy of wound treatment.

\section{Materials and Methods}

\subsection{Chemicals}

Papain was purchased from Sigma (P4762). Acid-soluble medium molecular (MMC, $\mathrm{Mr}=200 \mathrm{kDa})$ and high molecular $(\mathrm{HMC}, \mathrm{Mr}=350 \mathrm{kDa})$ weight chitosans (Bioprogress, Shchelkovo Moscow region, Russia) were used as carriers for immobilization. Other chemicals were reagent grade and purchased from Sigma.

\subsection{Papain Immobilization on Chitosans}

The immobilization of papain on chitosans was performed using the adsorption approach developed previously for other proteases [80,81]. Briefly, chitosan (1 g) was hydrated by $24 \mathrm{~h}$ incubation in pure water, washed three times in water, and transferred into $20 \mathrm{~mL}$ of papain solution $\left(1 \mathrm{mg} \mathrm{mL}^{-1}\right)$ in various buffers as indicated in Tables 1 and 2 . The incubation was followed at $25^{\circ} \mathrm{C}$ with stirring for 4 or $5 \mathrm{~h}$ for medium or high molecular weight chitosan, respectively. Next the chitosan was washed three times with the same buffer by decanting and dried overnight at $25^{\circ} \mathrm{C}$.

\subsection{Proteolytic Activity Measurements}

The proteolytic activity was evaluated by measuring the absorbance at $410 \mathrm{~nm}$ of fragments of proteolytic digestion of azocasein (Sigma-Aldrich, St. Louis, MO, USA), as described previously [82], with modifications [49].

\subsection{Kinetic Properties}

The enzymatic constants $\left(\mathrm{K}_{\mathrm{m}}, \mathrm{V}_{\max }\right)$ of free and chitosan-immobilized papain were calculated according to the Michaelis-Menden curve and Lineweaver-Burk double reciprocal models by carrying out the enzymatic assay on azocasein $(0.1-100.0 \mu \mathrm{M})$ in $50 \mathrm{mM}$ Tris- $\mathrm{HCl}$ buffer ( $\mathrm{pH}$ 7.5). The apparent $\mathrm{K}_{\mathrm{m}}$ and $\mathrm{V}_{\max }$ values were calculated. The enzyme turnover number $\mathrm{k}_{\text {cat }}$ was calculated from the Hanes-Woolf plot ([S]/v [S] plot). 


\subsection{Bacterial Strains and Growth Conditions}

Pseudomonas aeruginosa (ATCC 27853), Escherichia coli (MG 1655), Bacillus cereus (clinical isolate), Micrococcus luteus (clinical isolate), Staphylococcus aureus subsp. aureus (ATCC 29213), and Staphylococcus epidermidis (clinical isolate) were used for the biofilm assays. Clinical isolates were obtained from Kazan Institute of Epidemiology and Microbiology (Kazan, Russia). Bacterial strains were maintained and grown on the LB medium. The Basal medium (BM) (glucose $5 \mathrm{~g}$, peptone $7 \mathrm{~g}$, $\mathrm{MgSO}_{4} \bullet 7 \mathrm{H}_{2} \mathrm{O} 2.0 \mathrm{~g}$ and $\mathrm{CaCl}_{2} \bullet 2 \mathrm{H}_{2} \mathrm{O} 0.05 \mathrm{~g}$ in $1.0 \mathrm{~L}$ tap water) was used for the biofilm formation assays [83,84]. To obtain rigid biofilms, bacteria were grown for $48 \mathrm{~h}$ under static conditions at $37^{\circ} \mathrm{C}$ [84].

\subsection{Determination of Minimum Inhibitory Concentration (MIC)}

The MIC of antimicrobials was determined by the broth microdilution method in 96-well microtiter plates (Eppendorf) according to the EUCAST recommendations [85]. Briefly, the bacterial suspension containing $10^{8} \mathrm{CFUs} \mathrm{mL}^{-1}$ was subsequently diluted 1:300 with $\mathrm{BM}$ broth in microwell plates to obtain a $10^{6}$ cells $\mathrm{mL}^{-1}$ suspension and incubated at $37^{\circ} \mathrm{C}$ for $24 \mathrm{~h}$. Antimicrobials were added in the concentration range of $0.25-512 \mathrm{mg} \mathrm{L}^{-1}$. The MIC was determined as the lowest concentration of antimicrobial providing no visible bacterial growth after $24 \mathrm{~h}$ of incubation. To determine the $\mathrm{MBC}, 10 \mu \mathrm{L}$ of culture liquid from wells without visible growth was seeded into $1 \mathrm{~mL}$ of fresh broth and incubated at $37^{\circ} \mathrm{C}$ for $24 \mathrm{~h}$. The antibiotic concentration corresponding to the absence of growth was considered as MBC.

\subsection{Biofilm Assays}

The bacterial biofilms were grown $48 \mathrm{~h}$ in BM broth in 24-well TC-treated polystyrol plates $(1 \mathrm{~mL}$ per well). Then, the broth was exchanged with fresh broth supplemented with either soluble or chitosan-immobilized papain. After $24 \mathrm{~h}$ incubation, the plates were subjected to crystal violet staining [86]. To evaluate the potentiation of antimicrobials efficiency against biofilm-embedded cells by combination with enzymatic treatment, ciprofloxacin, gentamycin, or benzalkonium chloride was added at their respective $8 \times$ MBCs together with either soluble or chitosan-immobilized papain at the total protein concentration of $100 \mu \mathrm{g} \mathrm{mL}{ }^{-1}$. After $24 \mathrm{~h}$ of incubation, the wells were analyzed by CFUs counting by drop plate assay [87] with modifications [88] using in-house developed software [89].

\subsection{Statistical Analysis}

Experiments were carried out in biological triplicates (i.e., newly prepared cultures and medium) with three technical repeats in each one. The statistical significance of results was assessed using the Kruskal-Wallis statistical test with significance threshold at $p<0.05$. The enzymes half-inactivation time was calculated by plotting $\log _{10}($ time) vs. percentage of residual enzyme activity in GraphPad Prism 6 (GraphPad Software, San Diego, CA, USA, www.graphpad.com, access date 11 March 2021).

Author Contributions: Conceptualization-A.R.K. and M.G.H.; methodology-D.R.B., E.Y.T., M.I.B., V.A.K., and S.S.O.; investigation-D.R.B., E.Y.T., V.A.K., and S.S.O.; formal analysis-M.I.B., V.G.A., M.G.H., and A.R.K.; resources-M.G.H. and A.R.K.; visualization-D.R.B. and E.Y.T.; project administration-M.G.H. and A.R.K.; supervision-M.G.H. and A.R.K.; funding acquisition-M.G.H. and A.R.K.; writing—original draft preparation, review and editing—M.G.H., M.I.B., and A.R.K. All authors have read and agreed to the published version of the manuscript.

Funding: This research was supported by the Russian Foundation for Basic Research (RFBR-1934-90061 to AK, in the part concerning the anti-biofilm activity), and by the Ministry of Education and Science of the Russian Federation (No. FZGU-2020-0044 to VA, in the part concerning the immobilization assays).

Data Availability Statement: The data presented in this study are available on request from the corresponding author.

Conflicts of Interest: The authors declare no conflict of interest. 


\section{References}

1. Haesaerts, S.; Buitrago, J.A.R.; Loris, R.; Baeyens-Volant, D.; Azarkan, M. Crystallization and preliminary X-ray analysis of four cysteine proteases from Ficus carica latex. Acta Crystallogr. Sect. F Struct. Biol. Commun. 2015, 71, 459-465. [CrossRef]

2. Zare, H.; Moosavi-Movahedi, A.A.; Salami, M.; Mirzaei, M.; Saboury, A.A.; Sheibani, N. Purification and autolysis of the ficin isoforms from fig (Ficus carica cv. Sabz) latex. Phytochemistry 2013, 87, 16-22. [CrossRef] [PubMed]

3. Lim, T.K. Edible Medicinal and Non-Medicinal Plants: Volume 1, Fruits; Springer: Berlin/Heidelberg, Germany, 2012 ; pp. 1-835. [CrossRef]

4. Mohr, T.; Desser, L. Plant proteolytic enzyme papain abrogates angiogenic activation of human umbilical vein endothelial cells (HUVEC) in vitro. BMC Complementary Altern. Med. 2013, 13. [CrossRef]

5. Vootukuri, R.S.; Phillpot, M.P.; Trigiante, G. Fluorimetric ex vivo quantification of protease debriding efficacy on natural substrate. Wound Repair Regen. 2020, 28, 844-847. [CrossRef] [PubMed]

6. Vasconcelos, N.F.; Cunha, A.P.; Ricardo, N.; Freire, R.S.; Vieira, L.D.P.; Santa Brigida, A.I.; Borges, M.D.; Rosa, M.D.; Vieira, R.S.; Andrade, F.K. Papain immobilization on heterofunctional membrane bacterial cellulose as a potential strategy for the debridement of skin wounds. Int. J. Biol. Macromol. 2020, 165, 3065-3077. [CrossRef] [PubMed]

7. Tadikonda, A.; Pentapati, K.C.; Urala, A.S.; Acharya, S. Anti-plaque and anti-gingivitis effect of Papain, Bromelain, Miswak and Neem containing dentifrice: A randomized controlled trial. J. Clin. Exp. Dent. 2017, 9, e649-e653. [CrossRef] [PubMed]

8. Mugita, N.; Nambu, T.; Takahashi, K.; Wang, P.L.; Komasa, Y. Proteases, actinidin, papain and trypsin reduce oral biofilm on the tongue in elderly subjects and in vitro. Arch. Oral Biol. 2017, 82, 233-240. [CrossRef] [PubMed]

9. Mohamed, S.H.; Mohamed, M.S.; Khalil, M.S.; Mohamed, W.S.; Mabrouk, M.I. Antibiofilm activity of papain enzyme against pathogenic Klebsiella pneumoniae. J. Appl. Pharm. Sci. 2018, 6, 163-168. [CrossRef]

10. Song, Y.J.; Yu, H.H.; Kim, Y.J.; Lee, N.K.; Paik, H.D. The use of papain for the removal of biofilms formed by pathogenic Staphylococcus aureus and Campylobacter jejuni. LWT Food Sci. Technol. 2020, 127. [CrossRef]

11. Atacan, K.; Ozacar, M. Investigation of antibacterial properties of novel papain immobilized on tannic acid modified $\mathrm{Ag} / \mathrm{CuFe} 2 \mathrm{O} 4$ magnetic nanoparticles. Int. J. Biol. Macromol. 2018, 109, 720-731. [CrossRef] [PubMed]

12. Trizna, E.; Baydamshina, D.; Kholyavka, M.; Sharafutdinov, I.; Hairutdinova, A.; Khafizova, F.; Zakirova, E.; Hafizov, R.; Kayumov, A. Soluble and immobilized papain and trypsin as destroyers of bacterial biofilms. Genes Cells 2016, 10, $106-112$.

13. Garcia-Galan, C.; Berenguer-Murcia, A.; Fernandez-Lafuente, R.; Rodrigues, R.C. Potential of Different Enzyme Immobilization Strategies to Improve Enzyme Performance. Adv. Synth. Catal. 2011, 353, 2885-2904. [CrossRef]

14. Hanefeld, U.; Cao, L.Q.; Magner, E. Enzyme immobilisation: Fundamentals and application. Chem. Soc. Rev. 2013, 42, 6211-6212. [CrossRef]

15. Homaei, A.; Samari, F. Investigation of activity and stability of papain by adsorption on multi-wall carbon nanotubes. Int. J. Biol. Macromol. 2017, 105, 1630-1635. [CrossRef] [PubMed]

16. Bolivar, J.M.; Mateo, C.; Rocha-Martin, J.; Cava, F.; Berenguer, J.; Fernandez-Lafuente, R.; Guisana, J.M. The adsorption of multimeric enzymes on very lowly activated supports involves more enzyme subunits: Stabilization of a glutamate dehydrogenase from Thermus thermophilus by immobilization on heterofunctional supports. Enzym. Microb. Technol. 2009, 44, 139-144. [CrossRef]

17. Min, K.; Yoo, Y.J. Recent progress in nanobiocatalysis for enzyme immobilization and its application. Biotechnol. Bioprocess. Eng. 2014, 19, 553-567. [CrossRef]

18. Rodrigues, R.C.; Ortiz, C.; Berenguer-Murcia, A.; Torres, R.; Fernandez-Lafuente, R. Modifying enzyme activity and selectivity by immobilization. Chem. Soc. Rev. 2013, 42, 6290-6307. [CrossRef] [PubMed]

19. Cipolatti, E.P.; Valerio, A.; Henriques, R.O.; Moritz, D.E.; Ninow, J.L.; Freire, D.M.G.; Manoel, E.A.; Fernandez-Lafuente, R.; de Oliveira, D. Nanomaterials for biocatalyst immobilization-State of the art and future trends. RSC Adv. 2016, 6, 104675-104692. [CrossRef]

20. Gobom, J.; Nordhoff, E.; Ekman, R.; Roepstorff, P. Rapid micro-scale proteolysis of proteins for MALDI-MS peptide mapping using immobilized trypsin. Int. J. Mass Spectrom. 1997, 169, 153-163. [CrossRef]

21. He, Z.Y.; Nie, H.L.; Zhou, Y.T.; Zhu, L.M. Analysis of papain adsorption on nylon-based immobilized copper ion affinity membrane. J. Biotechnol. 2008, 136, S307. [CrossRef]

22. Zhang, H.T.; Nie, H.L.; Li, S.B.; Xue, Y.; Zhu, L.M. Electrospun nylon nanofiber as affinity membrane for papain adsorption. J. Biotechnol. 2008, 136, S416. [CrossRef]

23. Xue, Y.; Nie, H.L.; Zhu, L.M.; Li, S.B.; Zhang, H.T. Immobilization of Modified Papain with Anhydride Groups on Activated Cotton Fabric. Appl. Biochem. Biotechnol. 2010, 160, 109-121. [CrossRef]

24. Alpay, P.; Uygun, D.A. Usage of immobilized papain for enzymatic hydrolysis of proteins. J. Mol. Catal. B Enzym. 2015, 111, 56-63. [CrossRef]

25. Chen, Y.Y.; Lu, Y.H.; Ma, C.H.; Tao, W.W.; Zhu, J.J.; Zhang, X. A novel elastic liposome for skin delivery of papain and its application on hypertrophic scar. Biomed. Pharmacother. 2017, 87, 82-91. [CrossRef] [PubMed]

26. Homaei, A.A.; Sajedi, R.H.; Sariri, R.; Seyfzadeh, S.; Stevanato, R. Cysteine enhances activity and stability of immobilized papain. Amino Acids 2010, 38, 937-942. [CrossRef] [PubMed]

27. Li, F.Y.; Xing, Y.J.; Ding, X. Immobilization of papain on cotton fabric by sol-gel method. Enzym. Microb. Technol. 2007, 40, 1692-1697. [CrossRef] 
28. Manosroi, A.; Chankhampan, C.; Manosroi, W.; Manosroi, J. Toxicity Reduction and MMP-2 Stimulation of Papain and Bromelain Loaded in Elastic Niosomes. J. Biomed. Nanotechnol. 2012, 8, 720-729. [CrossRef] [PubMed]

29. Moreno-Cortez, I.E.; Romero-Garcia, J.; Gonzalez-Gonzalez, V.; Garcia-Gutierrez, D.I.; Garza-Navarro, M.A.; Cruz-Silva, R. Encapsulation and immobilization of papain in electrospun nanofibrous membranes of PVA cross-linked with glutaraldehyde vapor. Mater. Sci. Eng. C Mater. Biol. Appl. 2015, 52, 306-314. [CrossRef]

30. Muller, C.; Perera, G.; Konig, V.; Bernkop-Schnurch, A. Development and in vivo evaluation of papain-functionalized nanoparticles. Eur. J. Pharm. Biopharm. 2014, 87, 125-131. [CrossRef]

31. Pinto, C.; Lopes, P.S.; Sarruf, F.D.; Polakiewicz, B.; Kaneko, T.M.; Baby, A.R.; Velasco, M.V.R. Comparative study of the stability of free and modified papain incorporated in topical formulations. Braz. J. Pharm. Sci. 2011, 47, 751-760. [CrossRef]

32. Sangeetha, K.; Abraham, T.E. Chemical modification of papain for use in alkaline medium. J. Mol. Catal. B Enzym. 2006, 38, 171-177. [CrossRef]

33. Sim, Y.C.; Lee, S.G.; Lee, D.C.; Kang, B.Y.; Park, K.M.; Lee, J.Y.; Kim, M.S.; Chang, I.S.; Rhee, J.S. Stabilization of papain and lysozyme for application to cosmetic products. Biotechnol. Lett. 2000, 22, 137-140. [CrossRef]

34. Chatla, S.; Sivareddy, C.; Basaveswarao, M.; Harshita, E.; Yashwanthi, P. Anti-bacterial, anti-fungal and analgesic activity of papain conjugated quercetin. Eur. J. Biomed. 2017, 4, 280-285.

35. Adriano, W.S.; Filho, E.H.C.; Silva, J.A.; Giordano, R.L.C.; Goncalves, L.R.B. Stabilization of penicillin G acylase by immobilization on glutaraldehyde-activated chitosan. Braz. J. Chem. Eng. 2005, 22, 529-538. [CrossRef]

36. Manrich, A.; Galvao, C.M.A.; Jesus, C.D.F.; Giordano, R.C.; Giordano, R.L.C. Immobilization of trypsin on chitosan gels: Use of different activation protocols and comparison with other supports. Int. J. Biol. Macromol. 2008, 43, 54-61. [CrossRef] [PubMed]

37. Mei, S.; Han, P.P.; Wu, H.; Shi, J.F.; Tang, L.; Jiang, Z.G. One-pot fabrication of chitin-shellac composite microspheres for efficient enzyme immobilization. J. Biotechnol. 2018, 266, 1-8. [CrossRef]

38. Silva, J.A.; Macedo, G.P.; Rodrigues, D.S.; Giordano, R.L.C.; Goncalves, L.R.B. Immobilization of Candida antarctica lipase B by covalent attachment on chitosan-based hydrogels using different support activation strategies. Biochem. Eng. J. 2012, 60, 16-24. [CrossRef]

39. Elchinger, P.H.; Delattre, C.; Faure, S.; Roy, O.; Badel, S.; Bernardi, T.; Taillefumier, C.; Michaud, P. Immobilization of proteases on chitosan for the development of films with anti-biofilm properties. Int. J. Biol. Macromol. 2015, 72, 1063-1068. [CrossRef]

40. Khor, E.; Lim, L.Y. Implantable applications of chitin and chitosan. Biomaterials 2003, 24, 2339-2349. [CrossRef]

41. Krajewska, B. Application of chitin- and chitosan-based materials for enzyme immobilizations: A review. Enzym. Microb. Technol. 2004, 35, 126-139. [CrossRef]

42. Ozturk, E.; Agalar, C.; Kececi, K.; Denkbas, E.B. Preparation and characterization of ciprofloxacin-loaded alginate/chitosan sponge as a wound dressing material. J. Appl. Polym. Sci. 2006, 101, 1602-1609. [CrossRef]

43. Urrutia, P.; Bernal, C.; Escobar, S.; Santa, C.; Mesa, M.; Wilson, L.; Illanes, A. Influence of Chitosan Derivatization on Its Physicochemical Characteristics and Its Use as Enzyme Support. J. Appl. Polym. Sci. 2014, 131. [CrossRef]

44. Kumar, M.; Muzzarelli, R.A.A.; Muzzarelli, C.; Sashiwa, H.; Domb, A.J. Chitosan chemistry and pharmaceutical perspectives. Chem. Rev. 2004, 104, 6017-6084. [CrossRef] [PubMed]

45. Li, H.B.; Du, Y.M.; Xu, Y.M. Adsorption and complexation of chitosan wet-end additives in papermaking systems. J. Appl. Polym. Sci. 2004, 91, 2642-2648. [CrossRef]

46. Muzzarelli, R.A.A.; Muzzarelli, C. Chitosan chemistry: Relevance to the biomedical sciences. Polysacch. 1 Struct. Charact. Use 2005, 186, 151-209. [CrossRef]

47. Nahar, S.; Mizan, M.F.R.; Ha, A.J.W.; Ha, S.D. Advances and Future Prospects of Enzyme-Based Biofilm Prevention Approaches in the Food Industry. Compr. Rev. Food Sci. Food Saf. 2018, 17, 1484-1502. [CrossRef] [PubMed]

48. Thallinger, B.; Prasetyo, E.N.; Nyanhongo, G.S.; Guebitz, G.M. Antimicrobial enzymes: An emerging strategy to fight microbes and microbial biofilms. Biotechnol. J. 2013, 8, 97-109. [CrossRef] [PubMed]

49. Baidamshina, D.R.; Koroleva, V.A.; Trizna, E.Y.; Pankova, S.M.; Agafonova, M.N.; Chirkova, M.N.; Vasileva, O.S.; Akhmetov, N.; Shubina, V.V.; Porfiryev, A.G.; et al. Anti-biofilm and wound-healing activity of chitosan-immobilized Ficin. Int. J. Biol. Macromol. 2020. [CrossRef] [PubMed]

50. Niazi, S.A.; Al-Ali, W.M.; Patel, S.; Foschi, F.; Mannocci, F. Synergistic effect of $2 \%$ chlorhexidine combined with proteolytic enzymes on biofilm disruption and killing. Int. Endod. J. 2015, 48, 1157-1167. [CrossRef] [PubMed]

51. Baidamshina, D.R.; Trizna, E.Y.; Holyavka, M.G.; Bogachev, M.I.; Artyukhov, V.G.; Akhatova, F.S.; Rozhina, E.V.; Fakhrullin, R.F.; Kayumov, A.R. Targeting microbial biofilms using Ficin, a nonspecific plant protease. Sci. Rep. 2017, 7. [CrossRef] [PubMed]

52. Fernandez-Lucas, J.; Castaneda, D.; Hormigo, D. New trends for a classical enzyme: Papain, a biotechnological success story in the food industry. Trends Food Sci. Technol. 2017, 68, 91-101. [CrossRef]

53. Medeiros. Study of the effectiveness of papain in wound healing and specific approach to its application in patients with venous ulcers: A systematic review. Adv. Plast. Reconstr. Surg. 2018, 2, 183-187.

54. Azevedo, F.F.; Santanna, L.P.; Bobbo, V.C.; Libert, E.A.; Araujo, E.P.; Saad, M.A.; Lima, M.H.M. Evaluating the Effect of $3 \%$ Papain Gel Application in Cutaneous Wound Healing in Mice. Wounds A Compend. Clin. Res. Pract. 2017, $29,96-101$.

55. Porsani, M.Y.H.; Carvalho, L.A.R.; Pereira, C.S.; Paludetti, M.; Zangeronimo, M.G.; Pereira, L.J. The use of papain gel cream and sunflower oil in promoting healing in a wound in dogs: Three case reports. Arq. Bras. De Med. Vet. E Zootec. 2016, 68, 1201-1206. [CrossRef] 
56. Ribeiro, A.P.L.; de Oliveira, B.; Soares, M.F.; Barreto, B.M.F.; Futuro, D.O.; de Castilho, S.R. Effectiveness of $2 \%$ and $4 \%$ papain gels in the healing of venous ulcers. Rev. Da Esc. De Enferm. Da USP 2015, 49, 394-400. [CrossRef]

57. Dai, T.H.; Tanaka, M.; Huang, Y.Y.; Hamblin, M.R. Chitosan preparations for wounds and burns: Antimicrobial and woundhealing effects. Expert Rev. Anti-Infect. Ther. 2011, 9, 857-879. [CrossRef]

58. Younes, I.; Rinaudo, M. Chitin and Chitosan Preparation from Marine Sources. Structure, Properties and Applications. Mar. Drugs 2015, 13, 1133-1174. [CrossRef]

59. Bracco, L.F.; Levin, G.J.; Urtasun, N.; del Canizo, A.A.N.; Wolman, F.J.; Miranda, M.V.; Cascone, O. Covalent immobilization of soybean seed hull urease on chitosan mini-spheres and the impact on their properties. Biocatal. Agric. Biotechnol. 2019, 18. [CrossRef]

60. Klein, M.P.; Hackenhaar, C.R.; Lorenzoni, A.S.G.; Rodrigues, R.C.; Costa, T.M.H.; Ninow, J.L.; Hertz, P.F. Chitosan crosslinked with genipin as support matrix for application in food process: Support characterization and beta-D-galactosidase immobilization. Carbohydr. Polym. 2016, 137, 184-190. [CrossRef]

61. Ma, H.F.; Meng, G.; Cui, B.K.; Si, J.; Dai, Y.C. Chitosan crosslinked with genipin as supporting matrix for biodegradation of synthetic dyes: Laccase immobilization and characterization. Chem. Eng. Res. Des. 2018, 132, 664-676. [CrossRef]

62. Fini, A. The Role of Chitosan in Drug Delivery. Am. J. Drug Deliv. 2003, 1, 43-59. [CrossRef]

63. Johnson, K.A. Role of induced fit in enzyme specificity: A molecular forward/reverse switch. J. Biol. Chem. 2008, 283, 26297-26301. [CrossRef] [PubMed]

64. Michel, D. Conformational selection or induced fit? New insights from old principles. Biochimie 2016, 128, 48-54. [CrossRef]

65. dos Santos, J.C.S.; Barbosa, O.; Ortiz, C.; Berenguer-Murcia, A.; Rodrigues, R.C.; Fernandez-Lafuente, R. Importance of the Support Properties for Immobilization or Purification of Enzymes. Chemcatchem 2015, 7, 2413-2432. [CrossRef]

66. Mateo, C.; Grazu, V.; Pessela, B.C.C.; Montes, T.; Palomo, J.M.; Torres, R.; Lopez-Gallego, F.; Fernandez-Lafuente, R.; Guisan, J.M. Advances in the design of new epoxy supports for enzyme immobilization-stabilization. Biochem. Soc. Trans. 2007, 35, 1593-1601. [CrossRef] [PubMed]

67. Akila, M.; Sushama, A.; Kumaresan, R. Study on in vitro cytotoxicity of papain against liver cancer cell line Hep G2. Int. J. Pharm. Pharm. Sci. 2014, 6, 160-161.

68. Chandran, S.P.; Nachinmuthu, K.P.; Natarajan, S.B.; Inamdar, M.G.; Shahimi, M. Papain Loaded Solid Lipid Nanoparticles for Colorectal Cancer Therapy. Curr. Cancer Ther. Rev. 2018, 14, 75-87. [CrossRef]

69. Chankhampan, C.; Manosroi, J.; Yamamoto, H.; Tahara, K.; Manosroi, W.; Kawashima, Y.; Manosroi, A. Chemical stability enhancement and cytotoxicity reduction of papain loaded in PLGA nanospheres. J. Exp. Nanosci. 2014, 9, 138-151. [CrossRef]

70. Silva, Z.S.; Huang, Y.Y.; de Freitas, L.F.; Franca, C.M.; Botta, S.B.; Ana, P.A.; Mesquita-Ferrari, R.A.; Fernandes, K.P.S.; Deana, A.; Leal, C.R.L.; et al. Papain gel containing methylene blue for simultaneous caries removal and antimicrobial photoinactivation against Streptococcus mutans biofilms. Sci. Rep. 2016, 6. [CrossRef]

71. Kirker, K.R.; James, G.A. In vitro studies evaluating the effects of biofilms on wound-healing cells: A review. Apmis 2017, 125, 344-352. [CrossRef] [PubMed]

72. Atshan, S.S.; Shamsudin, M.N.; Sekawi, Z.; Lung, L.T.T.; Barantalab, F.; Liew, Y.K.; Alreshidi, M.A.; Abduljaleel, S.A.; Hamat, R.A. Comparative proteomic analysis of extracellular proteins expressed by various clonal types of Staphylococcus aureus and during planktonic growth and biofilm development. Front. Microbiol. 2015, 6. [CrossRef]

73. Lewis, K. Riddle of biofilm resistance. Antimicrob. Agents Chemother. 2001, 45, 999-1007. [CrossRef]

74. Cosgrove, S.E.; Kaye, K.S.; Eliopoulous, G.M.; Carmeli, Y. Health and economic outcomes of the emergence of third-generation cephalosporin resistance in Enterobacter species. Arch. Intern. Med. 2002, 162, 185-190. [CrossRef]

75. Sanchez-Vizuete, P.; Orgaz, B.; Aymerich, S.; Le Coq, D.; Briandet, R. Pathogens protection against the action of disinfectants in multispecies biofilms. Front. Microbiol. 2015, 6. [CrossRef]

76. Raafat, D.; Otto, M.; Reppschlager, K.; Iqbal, J.; Holtfreter, S. Fighting Staphylococcus aureus Biofilms with Monoclonal Antibodies. Trends Microbiol. 2019, 27, 303-322. [CrossRef]

77. Adamus-Bialek, W.; Vollmerhausen, T.L.; Janik, K. Hydrogen peroxide stimulates uropathogenic Escherichia coli strains to cellulose production. Microb. Pathog. 2019, 126, 287-291. [CrossRef]

78. Izano, E.A.; Amarante, M.A.; Kher, W.B.; Kaplan, J.B. Differential roles of poly-N-acetylglucosamine surface polysaccharide and extracellular DNA in Staphylococcus aureus and Staphylococcus epidermidis biofilms. Appl. Environ. Microbiol. 2008, 74, 470-476. [CrossRef] [PubMed]

79. Singh, R.; Ray, P.; Das, A.; Sharma, M. Penetration of antibiotics through Staphylococcus aureus and Staphylococcus epidermidis biofilms. J. Antimicrob. Chemother. 2010, 65, 1955-1958. [CrossRef] [PubMed]

80. Holyavka, M.G.; Kayumov, A.R.; Baydamshina, D.R.; Koroleva, V.A.; Trizna, E.Y.; Trushin, M.V.; Artyukhov, V.G. Efficient fructose production from plant extracts by immobilized inulinases from Kluyveromyces marxianus and Helianthus tuberosus. Int. J. Biol. Macromol. 2018, 115, 829-834. [CrossRef] [PubMed]

81. Holyavka, M.; Pankova, S.; Koroleva, V.; Vyshkvorkina, Y.; Lukin, A.; Kondratyev, M.; Artyukhov, V. Influence of UV radiation on molecular structure and catalytic activity of free and immobilized bromelain, ficin and papain. J. Photochem. Photobiol. B Biol. 2019, 201. [CrossRef] [PubMed]

82. Sabirova, A.R.; Rudakova, N.L.; Balaban, N.P.; Ilyinskaya, O.N.; Demidyuk, I.V.; Kostrov, S.V.; Rudenskaya, G.N.; Sharipova, M.R. A novel secreted metzincin metalloproteinase from Bacillus intermedius. FEBS Lett. 2010, 584, 4419-4425. [CrossRef] 
83. Kayumov, A.R.; Khakimullina, E.N.; Sharafutdinov, I.S.; Trizna, E.Y.; Latypova, L.Z.; Lien, H.T.; Margulis, A.B.; Bogachev, M.I.; Kurbangalieva, A.R. Inhibition of biofilm formation in Bacillus subtilis by new halogenated furanones. J. Antibiot. 2015, 68, 297-301. [CrossRef]

84. Trizna, E.Y.; Khakimullina, E.N.; Latypova, L.Z.; Kurbangalieva, A.R.; Sharafutdinov, I.S.; Evtyugin, V.G.; Babynin, E.V.; Bogachev, M.I.; Kayumov, A.R. Thio Derivatives of 2(5H)-Furanone As Inhibitors against Bacillus subtilis Biofilms. Acta Nat. 2015, 7, 102-107. [CrossRef]

85. Leclercq, R.; Canton, R.; Brown, D.F.J.; Giske, C.G.; Heisig, P.; MacGowan, A.P.; Mouton, J.W.; Nordmann, P.; Rodloff, A.C.; Rossolini, G.M.; et al. EUCAST expert rules in antimicrobial susceptibility testing. Clin. Microbiol. Infect. 2013, 19, 141-160. [CrossRef]

86. O'Toole, G.A.; Kolter, R. Initiation of biofilm formation in Pseudomonas fluorescens WCS365 proceeds via multiple, convergent signalling pathways: A genetic analysis. Mol. Microbiol. 1998, 28, 449-461. [CrossRef]

87. Herigstad, B.; Hamilton, M.; Heersink, J. How to optimize the drop plate method for enumerating bacteria. J. Microbiol. Methods 2001, 44, 121-129. [CrossRef]

88. Sharafutdinov, I.; Pavlova, A.; Khabibrakhmanova, A.; Kurbangalieva, A.; Kayumov, A. The antimicrobial effect of the 5-((-)bornyloxy)-2(5H)-furanone derivative on grampositive bacteria. FEBS J. 2017, 284, 143.

89. Bogachev, M.I.; Volkov, V.Y.; Markelov, O.A.; Trizna, E.Y.; Baydamshina, D.R.; Melnikov, V.; Murtazina, R.R.; Zelenikhin, P.V.; Sharafutdinov, I.S.; Kayumov, A.R. Fast and simple tool for the quantification of biofilm-embedded cells sub-populations from fluorescent microscopic images. PLoS ONE 2018, 13. [CrossRef] [PubMed] 